\title{
Liver enzymes in human undernutrition
}

\author{
BY K. L. MUKHERJEE AND N. K. SARKAR \\ School of Tropical Medicine, Calcutta, 12, India \\ (Received 22 December 1956-Revised 12 Fune 1957)
}

'The study of nutrition and the study of enzymes represent two sides of the same coin' (Green, 1946). This statement is specially applicable in cases of nutritional oedema and kwashiorkor, both being states of protein malnutrition. Since enzymes are protein in nature it is to be expected that protein malnutrition will lead to a diminution in the quantity of enzymes. Acute starvation in rats produces a marked reduction of liver nitrogen (Addis, Poo \& Lew, 1936; Campbell \& Kosterlitz, 1954; Vars \& Gurd, I947a,b). Campbell \& Kosterlitz (1948) showed that the protein content of the liver is directly related to the protein content of the diet; in inanition as well as on a protein-deficient diet the decrease of liver protein follows a steep curve in the first few days and later shows a slow linear decline. They attributed the initial rapid decline to the loss of what they termed 'labile liver cytoplasm'. Vars (1954) thought the labile liver cytoplasm to be associated with certain enzymic functions, whereas the remaining part is concerned with other enzymic activities. Schultz (1949) described the enzymes readily lost on fasting as 'labile'. Virtanen \& Winkler (1949) divided the liver enzymes into indispensable and dispensable according as they were preserved or lost during dietary restriction. In acute inanition Miller (1948) found in the rat a decrease of liver-catalase, alkaline-phosphatase, xanthine-dehydrogenase and cathepsin activities which paralleled and sometimes exceeded the loss of liver protein. Similarly, Rosenthal, Rogers, Vars \& Ferguson (1950) observed a loss of $68 \%$ in total arginase and rhodanase activities of the rat liver after a fast lasting 2 weeks. Axelrod $\&$ Elvehjem (I94I), after producing riboflavin deficiency in rats, found that the protein component of xanthine dehydrogenase formed a sensitive index of protein malnutrition. Bargoni (195I) showed a remarkable increase of liver alkaline phosphatase in protein malnutrition, whereas esterase, catalase and choline-oxidase activities declined and dipeptidase remained unchanged. Srinivasan \& Patwardhan (1955) noted an increase of alkaline phosphatase in malnutrition.

But data obtained for animals may not be directly relevant to man. Moreover, most of the animal experiments have been done in acute starvation and the findings obtained in such a condition will, of course, be different from those in chronic prolonged undernutrition, with which we are more specifically concerned. Research on human subjects is difficult, since only one tissue, blood, is readily available. Valuable data have been collected on the changes in blood enzymes in human starvation (Hutchinson, $195^{\mathrm{r}}$; Hutchinson, McCance \& Widdowson, I95I; Mukherjee \& Chaudhuri, I957; Mukherjee \& Werner, I954). Lately, the relative innocuousness of liver biopsy has been demonstrated. Waterlow (1954) and Waterlow \& Patrick (1954) in the West 
Indies found succinoxidase and cholinesterase activities of liver to be decreased in protein malnutrition.

This paper deals with the nitrogen content, catalase activity, iron content, and cholinesterase and alkaline-phosphatase activities of liver obtained on biopsy materials of twelve patients suffering from nutritional oedema and of seven babies with kwashiorkor.

\section{EXPERIMENTAL}

\section{Subjects}

The twelve patients, eight male and four female, suffering from nutritional oedema were aged from 12 to 58 years. The clinical findings on them have been summarized before (Mukherjee \& Chaudhuri, 1955; Mukherjee \& Jeliffe, I955). Diets which provided roughly $500-900 \mathrm{Cal}$. and $10-25 \mathrm{~g}$ protein daily had been taken for 4-6 months before oedema appeared. All the subjects had diarrhoea of non-specific origin, moderate dimorphic anaemia and severe hypoproteinaemia and hypoalbuminaemia. After admission to hospital they were put on a low-residue, high-protein diet, the quantity being gradually increased till they were taking 3000-4000 Cal. and $120-130 \mathrm{~g}$ protein daily.

The seven babies with kwashiorkor were aged from 8 months to 4 years; four were female and three male. In the weaning period they had diarrhoea, refractory to treatment; supplementary feeding had therefore been stopped and they were given barley water alone for 2-3 months, after which they developed the disease. Clinically, they had retardation of growth, oedema, crazy-pavement dermatoses, discoloured hair, enlarged, fatty liver and hypoalbuminaemia. After admission they were put on a diet of skim milk and fruit juice, and the clinical response was dramatic.

\section{Liver biopsy}

The initial biopsy was done within 3-4 days of admission and the second shortly before discharge. The interval between the two biopsies was 4-10 weeks. The biopsy material was blotted between filter-papers to remove any adhering blood and immediately weighed on a quartz-fibre torsion balance sensitive to $0.02 \mathrm{mg}$. The weighed tissue was then homogenized in a Potter-Elvehjem glass homogenizer at $0^{\circ}$ with $\mathrm{I} \mathrm{ml}$. ice-cold distilled water. The homogenized material was uniformly distributed, no connective tissue fragment was visible, no sieving was necessary and the material could be easily pipetted. The sample was then kept frozen till the actual determinations were made. The weight of the total tissue removed was between 18 and $33 \mathrm{mg}$ in two punctures. In no instance were more than two punctures made. Recovery from the operation was uneventful, except for traumatic pleurisy occurring in two patients.

\section{Analytical methods}

To estimate liver nitrogen $5 \mathrm{mg}$ tissue were digested with I ml. acid mixture (Kirk, I950) in a $5^{\circ} \mathrm{ml}$. micro-Kjedahl flask. A flask containing $\mathrm{I} \mathrm{ml}$. distilled water and I ml. acid mixture was similarly treated. After the completion of the digestion the flasks were cooled and $5 \mathrm{ml}$. water were added to each. The flask was then connected 
through a rubber stopper containing two tubes, one attached to an alkali reservoir through a stopcock and the other connected to a Pregl's steam-distillation apparatus. The ammonia was distilled into a boric-acid mixture containing bromocresol green and back-titrated with $0.005 \mathrm{~N}-\mathrm{H}_{2} \mathrm{SO}_{4}$.

Liver-catalase activity was estimated by the method of Young, Collier \& Homburger (1947). The results are expressed as $\mathrm{ml}$. oxygen liberated/mg N/sec.

Liver iron was estimated by a modification of Kennedy's(r 927 ) method. Five mg tissue were digested with $0.5 \mathrm{ml}$. conc. $\mathrm{H}_{2} \mathrm{SO}_{4}$ and $0.25 \mathrm{ml}$. perchloric acid. After digestion was complete the digests were cooled, diluted to ro $\mathrm{ml}$. and thoroughly cooled again after the addition of one drop nitric acid; $5 \mathrm{ml} .20 \%$ (w/v) KCNS and to ml. amyl alcohol were then added. The ferric thiocyanate in the amyl-alcohol layer was then compared with a similarly treated solution of standard iron in a Klett-Summerson photoelectric colorimeter with a $460 \mathrm{~m} \mu$ filter. The amyl alcohol was redistilled and all water used was doubly distilled with all-glass connexions. All reagents were of analytical grade. Even with all these precautions, some difficulties were encountered in iron estimations.

Liver-cholinesterase activity was measured by the method of Mollander, Friedman \& Ladue (1954). A tube containing buffered acetylcholine-chloride substrate was brought to $37^{\circ}$ together with two other tubes containing the buffer and distilled water respectively. To each, I mg tissue was added and the rack shaken from time to time during incubation for $2 \mathrm{~h}$. At the end of it, $7 \mathrm{ml}$. distilled water and $0.15 \mathrm{ml} .0 .005 \%$ methyl red were added to tubes I and 2. The third, control, tube was used as the blank. The three were centrifuged and the colour of the clear supernatant liquids was read in the Klett-Summerson photoelectric colorimeter with a $53 \circ \mathrm{m} \mu$ filter. The readings were compared with those of standards prepared from barbitone buffer (Michaelis, 1930). The activity is expressed as a unit change of $\mathrm{pH}$ in $2 \mathrm{~h} / \mathrm{mg}$ tissue.

Liver alkaline-phosphatase activity was determined by the method of Bodansky (1932-3) as modified by Hawk, Oser \& Summerson (1954). The results are expressed as $\mathrm{mg}$ phosphorus liberated/h/100 $\mathrm{g}$ liver tissue.

The amounts of material used to carry out the estimations after suitable dilution of the homogenate at the time of determination of the activities were:

For alkaline phosphatase, $4 \mathrm{mg}$ ( $2 \mathrm{mg}$ for control and $2 \mathrm{mg}$ for unknown); for cholinesterase, $3 \mathrm{mg}$ ( $\mathrm{r} \mathrm{mg}$ each for three tubes); for catalase, $2 \mathrm{mg}$ ( $\mathrm{Img}$ for blank and I $\mathrm{mg}$ for unknown); for iron, $5 \mathrm{mg}$; for nitrogen, $5 \mathrm{mg}$.

Duplicate estimations were undertaken whenever the amount of material permitted.

\section{RESULTS AND DISCUSSION}

Liver nitrogen. On admission the total nitrogen varied from 1300 to 1580 (mean I459) $\mathrm{mg} / \mathrm{IOO} \mathrm{g}$. Shortly before discharge the second biopsy showed nitrogen contents varying from 2100 to 2500 (mean 2268) $\mathrm{mg} / \mathrm{ro0}$ g. Details are given in Table $\mathrm{r}$.

During recovery from protein malnutrition, it is generally agreed that tissue-protein synthesis takes precedence over the replacement of plasma proteins (Elman, 1949). In these patients, therefore, in whom the serum proteins increased to a considerable 


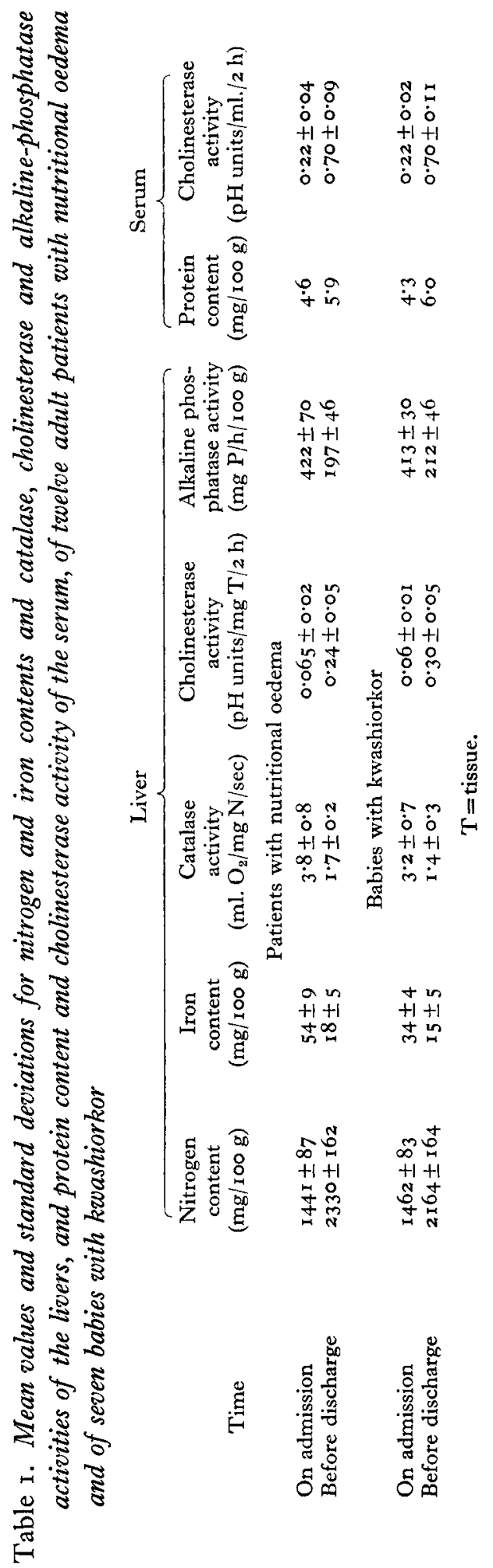


extent before discharge it can be assumed that the liver nitrogen content had regained its normal values. On this basis, in both kwashiorkor and nutritional oedema, the concentration of nitrogen in the liver may be assumed to have been reduced, on an average, by about one-third. It is also possible that the low nitrogen concentration in the initial biopsy material was a result of fatty infiltration or oedema (Waterlow, 1954, 1956). No conclusions may be drawn from the results as to the total amounts of nitrogen in the liver, but most probably there was a considerable loss (Waterlow, I956).

Catalase activity and iron content of the liver. It appears from Table $\mathrm{I}$ that from a mean initial activity of $3.6 \mathrm{ml} . \mathrm{O}_{2} / \mathrm{mg} \mathrm{N} / \mathrm{sec}$ the catalase activity came down to I. $6 \mathrm{ml} . \mathrm{O}_{2} / \mathrm{mg} \mathrm{N} / \mathrm{sec}$ after clinical recovery. The liver iron at the same time decreased from an initial value of $46 \mathrm{mg} / 100 \mathrm{~g}$ to $17 \mathrm{mg} / 100 \mathrm{~g}$. Thus, if we take the latter figures as normal, the catalase activity was increased $125 \%$ and iron $170 \%$ in the disease process. The finding of increased iron in protein malnutrition is supported by the observations of Uehlinger (1948), who found evidence of haemosiderosis in liver and spleen of the prisoners of the Warsaw Ghetto. Sherlock \& Walshe (I95I) and Waterlow ( 1948 ) found increased liver iron in malnourished infants.

Liver cholinesterase. As found by the present method, the liver-cholinesterase activity amounted on admission to 0.065 units $/ \mathrm{mg}$ tissue $/ 2 \mathrm{~h}$. The method was equally applicable to the liver tissues and to serum. For each determination there was a blank and a control tube and so no difficulty was experienced with initial $\mathrm{pH}$ of the homogenate. As the activity was rather small with the I $\mathrm{mg}$ of tissue available, extra precautions were taken with the preparation of the barbitone buffer, so that the standard curve was a linear one. Only glass-distilled water was used. Duplicate estimations agreed within $8 \%$.

It appears that the liver-cholinesterase activity was low on admission and increased after recovery. From the assumption that the synthesis of liver proteins and enzymes proceeds earlier than that of plasma proteins, the enzyme activity obtained after clinical recovery of the patients may be taken as the normal enzyme content of the subjects concerned. It therefore appears that there was on an average a $70 \%$ reduction of the cholinesterase content of the liver at the height of malnutrition. It is of interest that the serum cholinesterase was reduced to a slight extent (see also Mukherjee \& Chaudhuri, 1957). It is, therefore, possible that the serum cholinesterase is of hepatic origin. Waterlow (1950), using the Cartesian-diver technique, measured liver cholinesterase in malnourished infants and found a loss of pseudocholinesterase which increased after recovery. The meaning of the decrease of this enzyme in malnutrition is not clear. Lipman (quoted by Waterlow, 1954) suggested that the esterase may be concerned with the acetylation of amino-acids as a stage in the synthesis of protein, in which event the decreased activity in malnutrition may be explained as due to tissue atrophy (Potter, I949).

Liver alkaline phosphatase. In kwashiorkor, and more so in nutritional oedema, the liver alkaline-phosphatase activity was very high on admission. It averaged $420 \mathrm{mg}$ $\mathrm{P} / \mathrm{h} / 100 \mathrm{~g}$ wet weight, and was reduced to $200 \mathrm{mg} \mathrm{P} / \mathrm{h} / \mathrm{lo0} \mathrm{g}$ after recovery. If we express the values per $\mathrm{mg} \mathrm{N}$, the alkaline-phosphatase activity was $0.29 \mathrm{mg} \mathrm{P} / \mathrm{h} / \mathrm{mg} \mathrm{N}$ on admission and decreased to $0.09 \mathrm{mg} \mathrm{P} / \mathrm{h} / \mathrm{mg} \mathrm{N}$ after recovery. On this basis, it was 
increased more than $200 \%$ in states of protein malnutrition. It is perhaps surprising that an enzyme being protein in nature can be increased in a protein-deficiency state. However, kwashiorkor (Waterlow, I948) as well as nutritional oedema (Mukherjee \& Chaudhuri, 1955) is associated with the consumption of a predominantly carbohydrate diet which is severely deficient in protein. Hence, the body has to deal with much more carbohydrate relative to other food constituents. The increased liver alkalinephosphatase activity might be a reflection of the attempt to adjust the metabolism accordingly. Thus, Bodansky (1934) found an increase of serum alkaline phosphatase after carbohydrate ingestion and attributed it to increased functional activity.

In experimental animals, Miller (1948) found a decrease of alkaline phosphatase in acute inanition. Expressed as a percentage of wet weight, the activity remained more or less the same. Wachstein (1945), on the other hand, using histochemical methods found increase in cytoplasmic alkaline-phosphatase activity both in atrophic cells of the starved animals and in the hydropic cells of the protein-depleted rats and mice. A considerable increase of liver alkaline phosphatase on a protein-deficient diet was also shown by Bargoni (1951). It has been mentioned before that serum alkalinephosphatase activity in our patients was decreased in comparison with the values after recovery. Hence, the increased amount of liver alkaline phosphatase does not contribute materially to the amount of the enzyme present in the plasma.

\section{SUMMARY}

I. Twelve patients suffering from nutritional oedema and seven babies with kwashiorkor were subjected to liver biopsy on admission to hospital and after recovery. Liver nitrogen content, catalase activity, iron content and cholinesterase and alkalinephosphatase activity were determined.

2. The liver-nitrogen concentrations were low on admission and higher after recovery.

3. The catalase activity of the liver amounted to $3.6 \mathrm{ml} . \mathrm{O}_{2} / \mathrm{mg} \mathrm{N} / \mathrm{sec}$ on admission and to $1.6 \mathrm{ml} . \mathrm{O}_{2} / \mathrm{mg} \mathrm{N} / \mathrm{sec}$ after recovery. The liver iron at the same time decreased from an initial value of $46 \mathrm{mg} / \mathrm{r} 00 \mathrm{~g}$ to $17 \mathrm{mg} / \mathrm{r} 00 \mathrm{~g}$. There was a definite correlation between liver iron content and catalase activity.

4. There was a 70\% reduction of liver cholinesterase activity on admission compared with the value after recovery.

5. The liver alkaline-phosphatase activity was $200 \%$ higher on admission than after recovery.

\section{REFERENCES}

Addis, T., Poo, L. J. \& Lew, W. (1936). F. biol. Chem. ז15, Ix1.

Axelrod, A. E. \& Elvehjem, C. A. (1941). F. biol. Chem. r40, 725.

Bargoni, N. (1951). Experientia, 7, 104.

Bodansky, A. (1932-3). F. biol. Chem. 99, 197.

Bodansky, A. (1934). F. biol. Chem. 104, 473.

Campbell, R. M. \& Kosterlitz, H. W. (I948). Biochem. 7. 43, 416.

Campbell, R. M. \& Kosterlitz, H. W. (1954). Biochim. biophys. Acta, 8, 664.

Elman, R. (1949). Parenteral Alimentation. New York: Paul B. Howber Inc.

Green, D. E. (1946). In Currents in Biochemical Research, p. I49. [D. E. Green, editor.] New York: Interscience Publishers Inc. 
Hawk, B., Oser, B. L. \& Summerson, W. H. (1954). Practical Physiological Chemistry, 13th ed., p. 636. London: J. and A. Churchill.

Hutchinson, A. O. (195I). In Spec, Rep. Ser. med. Res. Coun., Lond., no. 275, p. 226.

Hutchinson, A. O., McCance, R. A. \& Widdowson, E. M. (195 I). In Spec. Rep. Ser. med. Res. Coun., Lond., no. 275 , p. 216.

Kennedy, R. P. (1927). \%. biol. Chem. 74, 385 .

Kirk, P. L. (I950). Quantitative Ultramicro Analysis, p. 177. New York: John Wiley and Sons, Inc. Michaelis, L. (1930). F. biol. Chem. 87, 33 .

Miller, L. L. (1948). F. biol. Chem. 172, 113 .

Mollander, D. W., Friedman, M. M. \& Ladue, J. S. (1954). Ann. intern. Med. 4I, I I39.

Mukherjee, K. L. \& Chaudhuri, R. N. (1955). Bull. Calcutta School trop. Med. 3, r.

Mukherjee, K. L. \& Chaudhuri, R. N. (1957). Bull. Calcutta School trop. Med. 5, r3.

Mukherjee, K. L. \& Jelliffe, D. B. (1955). F. trop. Paediat. I, 6 r.

Mukherjee, K. L. \& Werner, G. (1954). F. Lab. clin. Med. 43, 727.

Potter, V. R. (1949). In Respiratory Enzymes, p. 265. [H. A. Lardy, editor.] Minneapolis, Minnesota: Burgess Co.

Rosenthal, O., Rogers, C. S., Vars, H. M. \& Ferguson, C. C. (1950). F. biol. Chem. 185, 669.

Schultz, J. (1949). F. biol. Chem. 178, 45 I.

Sherlock, S. \& Walshe, V. (1951). In Spec. Rep. Ser. med. Res. Coun., Lond., no. 275, p. III.

Srinivasan, P. R. \& Patwardhan, V. N. (1955). Indian F. med. Res. 43, I.

Uehlinger, E. (1948). Quoted by A. Keys, J. Brožek, A. Henschel, O. Mickelsen \& H. L. Taylor (1950) in Biology of Human Starvation, p. 192. University of Minnesota Press.

Vars, H. M. (1954). Conference on Liver Injury. Transactions of the Twelfth Meeting, p. I 50. New York: Josiah Macy Jr. Foundation.

Vars, H. M. \& Gurd, F. N. (1947a). Amer. F. Physiol. r5r, 39 1.

Vars, H. M. \& Gurd, F. N. (1947b). Amer. F. Physiol. r5r, 398.

Virtanen, A. I. \& Winkler, U. (1949). Acta chem. scand. 3, 272.

Wachstein, M. (1945). Arch. Path. 40, 57.

Waterlow, J. C. (1948). Spec. Rep. Ser. med. Res. Coun., Lond., no. 263.

Waterlow, J. (1950). Lancet, 258, 908.

Waterlow, J. C. (1954). In Report of the Second Inter-African (C.C.T.A.) Conference on Nutrition, Gambia, 1952, p. I76. London: H.M. Stationery Office.

Waterlow, J. C. (1956). Personal communication.

Waterlow, J. C. \& Patrick, S. J. (1954). Ann. N.Y. Acad. Sci. 57, 750.

Young, N. F., Collier, V. \& Homburger, F. (1947). Proc. Soc. ex৯. Biol., N.Y., 66, 324. 